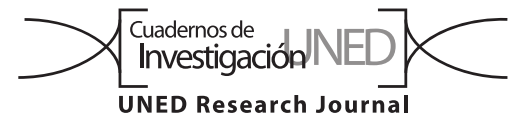

\title{
Heavy metal bio-accumulation in the kidneys of scaly and non-scaly fishes from Epe Lagoon, Nigeria
}

\author{
Olufemi David Owolabi' \& Olufunsho Awodele ${ }^{2}$ \\ 1. University of Ilorin, Department of Zoology, P.M.B. 1515, Ilorin 240003, Nigeria; olulabi47@yahoo.com \\ 2. University of Lagos, College of Medicine, Department of Pharmacology, Therapeutics \& Toxicology, P.M.B 12003 Idi-Araba, Lagos, Nigeria; \\ awodeleo@gmail.com
}

Received 01-XI-2018 • Corrected 17-I-2019 • Accepted 30-I-2019

\begin{abstract}
Introduction: Heavy metal contamination of aquatic ecosystems has been a serious concern throughout the world for many decades, and has caused devastating effects on aquatic organisms. Objective: To evaluate the levels of $\mathrm{Cu}, \mathrm{Zn}, \mathrm{Fe}, \mathrm{Pb}$ and $\mathrm{Cd}$ in the kidneys of scaly (T. zillii, M. rume and R. ocellatus) and non-scaly (C. gariepinus, Ch. nigrodigitatus and S. filamentosus) fishes in Epe lagoon, Nigeria to understanding the bioaccumulation potential of the kidney relative to other organs in fish that have previously been reported in literature. Methods: We studied concentrations of copper (Cu), iron (Fe), zinc $(\mathrm{Zn})$, cadmium $(\mathrm{Cd})$ and lead $(\mathrm{Pb})$ in the kidneys of 141 scaly fishes (Mo. rume, R. occellatus, T. zillii) and 134 non-scaly fishes (C. gariepinus, S.filamentosus, Ch. nigrodigitatus) and water samples obtained from Epe Lagoon using Standard Atomic Absorption Spectrometry methods. Results: The kidneys of $R$. ocellatus had the highest levels of Fe $(2,92 \pm 0,10)$ and $\mathrm{Cd}(0,18 \pm 0,03)$, while that of Ch. nigrodigitatus $(2,78 \pm 0,02)$ and T. zillii $(0,31 \pm 0,02)$ had the lowest concentration of Fe and $\mathrm{Cd}$ respectively. T. zillii and $M$. rume accumulated $\mathrm{Cu}$ and $\mathrm{Zn}$ in their kidneys respectively more than the others. There was no significant difference $(p<0,05)$ in mean trace metal concentrations among the scaly and non-scaly fishes. The concentrations of metals in fish specimens were below the FEPA and WHO prescribed maximum allowable limits in food fish. Dissolved oxygen $(9,0 \pm 0,02)$ and total alkalinity $(24,0 \pm 0,01)$ were above FEPA values (dissolved oxygen: $3,0-5,0 \mathrm{mg} / \mathrm{L}$ and total alkalinity: $3,05-5,3 \mathrm{mg} / \mathrm{L})$. The ranking of heavy metals distribution in the water body was $\mathrm{Cu}(4,70)>\mathrm{Fe}(0,72)>\mathrm{Zn} \quad(0,13)>\mathrm{Pb}(0,007)>\mathrm{Cd}$ $(0,006)$. Bioconcentration factor of $\mathrm{Zn}$ was generally high in all species. Conclusion: Close monitoring of these metals in the fishes and the lagoon is important to ensure the safety of fish consumers in the area.
\end{abstract}

Key words: fishes, heavy metals, Epe Lagoon, bioconcentration factor, kidney.
RESUMEN: "Bioacumulación de metales pesados en los riñones de peces escamosos y no escamosos de la Laguna Epe, Nigeria". Introducción: La contaminación por metales pesados de los ecosistemas acuáticos ha sido una gran preocupación en todo el mundo durante muchas décadas y ha causado efectos devastadores en los organismos acuáticos. Objetivo: Evaluar los niveles de $\mathrm{Cu}, \mathrm{Zn}, \mathrm{Fe}, \mathrm{Pb}$ y $\mathrm{Cd}$ en los riñones de peces escamosos (T. zillii, M. rume y $R$. ocellatus) y no escamosos (C. gariepinus, Ch. Nigrodigitatus y S. filamentosus) en la Laguna Epe, Nigeria, para comprender el potencial de bioacumulación del riñón en relación con otros órganos en peces que se han descrito anteriormente en la literatura. Métodos: Estudiamos las concentraciones de cobre $(\mathrm{Cu})$, hierro $(\mathrm{Fe})$, zinc $(\mathrm{Zn})$, cadmio $(\mathrm{Cd})$ y plomo $(\mathrm{Pb})$ en los riñones de 141 peces escamosos (M. rume, R. occellatus, T. zillii) y 134 peces no escamosos (C. gariepinus, S. filamentosus, Ch. nigrodigitatus) y muestras de agua obtenidas de la Laguna Epe utilizando métodos estándar de espectrometría de absorción atómica. Resultados: Los riñones de $R$. ocellatus tuvieron los niveles más altos de Fe $(2,92 \pm 0,10)$ y $\mathrm{Cd}(0,18 \pm 0,03)$, mientras que el de $C h$. nigrodigitatus $(2,78 \pm 0,02)$ y $T$. zillii $(0,31 \pm 0,02)$ tuvieron la concentración más baja de Fe y Cd, respectivamente. T. zillii y $M$. rume acumularon $\mathrm{Cu}$ y $\mathrm{Zn}$ en sus riñones, respectivamente, más que los otros. No hubo diferencias significativas $(p<0,05)$ en las concentraciones medias de metales traza entre los peces escamosos y no escamosos. Las concentraciones de metales en las muestras de peces estaban por debajo de los límites máximos permisibles por la FEPA y la OMS para peces comestibles. El oxígeno disuelto $(9,0 \pm 0,02)$ y la alcalinidad total $(24,0 \pm 0,01)$ estaban por encima de los valores de FEPA (oxígeno disuelto: $3,0-5,0 \mathrm{mg} / \mathrm{L}$ y la alcalinidad total: 3,05-5, 3mg/L). La clasificación de la distribución de metales pesados en el cuerpo de agua fue $\mathrm{Cu}(4,70)>\mathrm{Fe}(0,72)>\mathrm{Zn}(0,13)>\mathrm{Pb}(0,007)>\mathrm{Cd}$ $(0,006)$. El factor de bioconcentración de $\mathrm{Zn}$ fue generalmente alto en todas las especies. Conclusión: El monitoreo cercano de estos metales en los peces y la laguna es importante para garantizar la seguridad de los consumidores de pescado en el área.

Palabras clave: peces, metales pesados, Laguna Epe, factor de bioconcentración, riñón. 
Heavy metal contamination of aquatic ecosystems has been a serious concern throughout the world for many decades, as it has caused devastating effects on the ecological balance of the recipient environment and a diversity of aquatic organisms (Farombi, Adelowo, \& Ajimoko, 2007); where their concentrations are in excess of optimum or maximum levels. Metals are non-biodegradable and are considered as major environmental pollutants causing cytotoxic, mutagenic and carcinogenic effects in animals (More, Rajput, \& Bandela, 2003). Predatory fishes are often at the top of aquatic food chain and may concentrate large amounts of some metals from the water (Mansour \& Sidky, 2002) and the discharges of waste water (Labonne, Ben Othman, \& Luck, 2001). Heavy metals may enter fish bodies in three possible ways; through the body surface (skin), gill or the digestive tract (Sarnowski, 2003). On absorption, the toxicants become accumulated in the gills, liver, gonads and the kidneys at higher concentrations than the muscles (Chatterjee, Jurgenson, Schroeder, Ealick, \& Begley, 2006). The consumption of such organisms may in turn lead to the accumulation of the metals in human body and cause neurotoxicity, lung and kidney cancer, mental retardation, damage of the nervous system and death (Zevenhoven \& Kilpinen, 2001). Measurement of accumulation patterns of heavy metals in tissues is therefore pertinent with respect to animal health and establishment of public health standard (Kalay \& Canli, 1999).

The lagoon systems in Lagos State, Nigeria comprises Badagry, Ologe, Lagos, Lekki, and Epe lagoons and they act as reservoirs receiving effluents of over $10000 \mathrm{~m}^{3}$ daily from drainages through different parts of the metropolis and hinterland (Adefemi, Asaolu, \& Olaofe, 2008). Several studies indicated the presence of heavy metals in these water bodies where there are thriving fisheries activities (Olowu et al., 2010). Epe lagoon $\left(2^{\circ} 50^{\prime} 00^{\prime \prime}-4^{\circ} 10^{\prime} 00^{\prime \prime} \mathrm{N}\right.$ $\& 5^{\circ} 30^{\prime} 00^{\prime \prime}-5^{\circ} 40^{\prime} 00^{\prime \prime} \mathrm{E}$ ) with a surface area of $243 \mathrm{~km}^{2}$ and average depth of about $1,80 \mathrm{~m}$ is bounded by Lagos lagoon on the West and Lekki lagoon on the East. The lagoon opens into the Gulf of Guinea via the Lagos harbour. The lagoon is very unique being the only lagoon in Nigeria that is sandwiched between brackish and freshwater systems and hence experience direct in-flow from the lagoon located upstream to it. Apart from serving as source of fisheries, Epe lagoon serves as medium of transportation for people, goods and log of timber from Epe metropolis to other South-Western parts of Nigeria. The close proximity of Epe metropolis and other riparian communities along Epe lagoon to Lagos, the commercial nerve centre of Nigeria, has led to increased population growth and urbanization of Epe area. This may have in turn led to environmental pollution occasioned by anthropogenic activities such as discharge of industrial, agricultural and domestic effluents replete with trace metals into the aquatic ecosystem. This study is therefore pertinent considering the health risk that heavy metals could pose to fish and people within the environment.

Accumulation of heavy metals in fish tissues/organs has been well documented but studies have generally been concentrated on muscle, being the part commonly consumed, and the gill or liver, where most of the metals are deposited; while the distribution pattern among other tissues/organs such as the kidney have received little attention. The kidneys are known as sophisticated reprocessing machine acting as body's refuse removal. Hence, they are rarely studied for their heavy metals bioaccumulation potentials relative to other parts such as gill and liver which are considered as store house of metals (Kalay \& Canli, 1999). However, when the ability of kidney in refuse removal is overwhelmed, it may accumulate high level of metals and like the gill and liver could serve as potential indicator of heavy metal pollution. Therefore, the choice of kidney for this study is predicated on its peculiar ability to reabsorb and accumulate divalent metals such as cadmium (Cd), iron (Fe), lead (Pb), zinc (Zn), etc. (Barbier, Jacquillet, Tauc, Cougnon, \& Poujeol, 2005). Vinodhini and Narayanan (2008) also reported that the kidney accumulates considerable amounts of heavy metals. Furthermore, the kidney like the muscle and liver is also consumed, so it is imperative to estimate its metal content.

The outer body of some fishes is covered with scales (Sharpe, 2001) while the body of some other species is covered instead by scutes (Gilbert, 1994). Others may have no outer covering on the skin; these are called naked fish or scale less fishes. (Lagler et al., 1977). Fish scales are used for protection, as they work like armour to shield fishes against predators scrapes parasites, prevent diseases and external injuries. They may also aid in locomotion, retention of moisture and protective coloration, such as camouflage and warnings to potential predators (Sharpe, 2001). Fishes without scales naturally absorb all the toxins in the water (Farombi et al., 2007). Perhaps it is highly probable that fishes with scales will accumulate trace elements in their tissues at relatively lower levels than non-scaly fishes. Absorption through the skin, however, is not the only route of entry of metals into fish tissues. Essentially, fish bio-accumulate metals through ingestion of food and other particulate matter suspended in water (Alam, Allinson, Stagnitti, Tanaka, \& Westbrooke, 2002). It is therefore plausible that accumulation of metals may be more regulated in scaly fishes as entry of metals is mainly restricted to ingestion of food as 
opposed to non-scaly fishes where metals may be assimilated both through the skin and ingestion of food.

Among the most commercially important fish species in the lagoon are C. gariepinus (Clariidae), Chrysicthys nigrodigitatus (Bagridae), Tilapia zillii (Cichlidae), Synodontis filamentosus (Mochokidae), Mormyrus rume (Mormyridae) and Rhinigobius ocellatus (Gobiidae). These fishes are highly relished either fresh or smoke dried and are readily available all year round. Fish species are plastic in their feeding habits and they subsist on any dietary items readily available in their environment (Owolabi, 2008). Since dietary uptake is the main mode of metal absorption in fish (Alam et al., 2002), it follows that likely ingested trace metals together with other dietary items may bio-accumulate in tissues, thus rendering them unfit for consumption. The concern that heavy metal contamination of food portends serious danger to the consumers prompted regulatory bodies like World Health Organization (WHO) and Federal Environmental Protection Agency (FEPA) to establish the optimum or maximum allowable concentrations for trace elements in food. The preponderance of $\mathrm{Cd}, \mathrm{Cu}, \mathrm{Fe}, \mathrm{Pb}$ and $\mathrm{Zn}$ among other metals mostly released from domestic, industrial and other anthropogenic activities informed their choice for this study.

The presence of nickel (Ni), chromium $(\mathrm{Cr})$ and lead $\mathrm{Pb})$ in higher concentrations in the tissues of some aquatic biota and surface water of Lagos lagoon has been reported (Okoye, 1991). Lawani and Alawode (1996) also reported higher concentrations of mercury $(\mathrm{Hg})$ and $\mathrm{Pb}$ in Clarias gariepinus from River Niger. Ovuru and Alfred-Ockiya (2001) observed that the accumulation of zinc ( $\mathrm{Zn}$ ), $\mathrm{Pb}$ (lead), iron (Fe) and $\mathrm{Hg}$ in the tissues of Panaeus notialis from the Brass River system of Niger delta, exceeded the WHO safe limit for food consumption. Similarly, while an increased levels of copper (Cu), Zn and $\mathrm{Pb}$ in Oreochromis niloticus from Delimi River (Omoregie, Okoronkwo, Eziashi, \& Zoakah, 2002) and Cu, Zn, Fe, cadmium (Cd) and manganese (Mn) in C. gariepinus from disused mining lakes in Jos (Akueshi, Oriegie, Ocheakiti, \& Okunsebor, 2003) were also recorded; Nwani et al. (2010) observed that the concentrations of $\mathrm{Cu}, \mathrm{Zn}$ and $\mathrm{Pb}$ in gills and muscles of six fish species from Afikpo were within the WHO and FEPA prescribed limit. Corresponding information on the concentrations of heavy metals in the tissues/organs of fish species in Epe lagoon are, however, scanty and none has reported on the comparison between accumulation of trace elements in scaly and nonscaly fishes. Therefore, baseline information that could be used by relevant bio-monitoring agencies to either prevent the build-up of heavy metals in water bodies and their biota or plan an intervention programme for remediation is imperative. This study evaluates the levels of $\mathrm{Cu}, \mathrm{Zn}, \mathrm{Fe}, \mathrm{Pb}$ and $\mathrm{Cd}$ in the kidneys of scaly (T. zillii, $M$. rume and $R$. ocellatus) and non-scaly (C. gariepinus, $C h$. nigrodigitatus and S. filamentosus) fishes in Epe lagoon, Nigeria; with a view to understanding the bioaccumulation potential of the kidney relative to other organs in fish that have previously been reported in literature.

\section{MATERIALS AND METHODS}

Collection of Fish: Samples were obtained according to the recommendation of United Nations Environment Programme (UNEP) reference method for marine pollution studies (Adeniyi \& Yusuf, 2007). Two hundred and seventy-five (275) juvenile specimens (length 9,12$12,15 \mathrm{~cm}$ ) of six different species used for the study viz scaly fishes (Mormyus rume; Rhinogobius ocellatus; Tilapia zillii) and non-scaly fishes (Clarias gariepinus; Synodontis filamentosus; Chrysichthys nigrodigitatus) were randomly collected from different locations using gill nets, cast nets and drag nets, which were usually left overnight by local fishermen. The netted fishes were recovered each morning in a picnic box with some quantity of lagoon water and transported to the laboratory. Each fish was properly cleaned by rinsing with distilled water to remove debris planktons and other external adherent. Fish was then drained under folds of filter, weighed, wrapped in aluminum foil and then frozen at $-10^{\circ} \mathrm{C}$ prior to analysis. For analysis, the fish samples were defrosted for two hours. The kidneys were removed using plastic knife, dried at $80^{\circ} \mathrm{C}$ for $2 \mathrm{~h}$ in Gallenkamp hot box oven and then blended in an electric moulinex blender. Each of the samples was weighed and ashed in the furnace at $550^{\circ} \mathrm{C}$ for $90 \mathrm{~min}$. The ash was dissolved in $5 \mathrm{~mL}$ of concentrated nitric acid and made up to $25 \mathrm{~mL}$. Atomic Absorption Spectrometer was used to determine the presence of copper, iron, zinc, cadmium and lead.

Water samples: Were obtained from Epe Lagoon (Fig. 1) using plastic containers. To $250 \mathrm{~mL}$ of water sample, $5 \mathrm{~mL}$ of concentrated hydrochloric acid was added and evaporated to $25 \mathrm{~mL}$. The concentrate was transferred to a $50 \mathrm{~mL}$ flask and diluted to mark with distilled water. Metal (copper, iron, zinc, cadmium and lead) contents were determined using 304u/c Atomic Absorption Spectrometer. The specific wavelengths used were $357,87 \mathrm{~nm}$ copper, 228,80nm, cadmium; 283,31 nm, lead; 232,0nm iron and $213,9 \mathrm{~nm}$ zinc. The calibration yielded a straight line and the absorbances of solutions of unknown concentrations were measured and the concentration determined from the calibration curve. The physicochemical parameters 
(alkalinity, pH, copper, iron, zinc, cadmium and lead) of the water samples were also determined following the method of the American Public Health Association (1975). Metal analysis was validated using standard addition. Two of the samples T. zillii (representing scaly fish) and S. filamentosus (representing non-scaly fish) were spiked with $\mathrm{Cu}, \mathrm{Zn}$ and $\mathrm{Pb}$ metals prepared from the standard $1000 \mathrm{mg} / \mathrm{L}$ stock solution (Romil, Cambridge UK) of the metals. The recovery levels were satisfactorily within the $75-125 \%$ recovery range for metals. Also blank determinations were carried out simultaneously with the samples and showed no presence of the metals analyzed. Bio-concentration factor (BCF) of each metal was evaluated using the following expression:

$$
\mathrm{BCF}=\frac{\text { Concentration of metal in fish }(\mu \mathrm{g} / \mathrm{g})}{\text { Concentration of metal in water }(\mu \mathrm{g} / \mathrm{g})}
$$

Statistical analysis: The data were analyzed for means and standard deviation. Statistically significant differences between the scaly group and the non-scaly groups were analyzed using student t-test. $P$ values less than 0,05 were considered significant.

Ethical, conflict of interest and financial statement: There is no competing interest both financially and non-financially that is associated to this research work. This research received no specific grant from any funding agency in the public, commercial or not-for-profit sectors.
This study was approved by the University of Ilorin, Nigeria ethical committee on the use of animals, and conformed to the Guide for the Care and Use of Laboratory Animals published by the U. S. National Institutes of Health (NIH Publication No. 85-23, revised 1996)" for studies involving experimental animals.

The authors designed and coordinated all laboratory experiments. They also conducted all experiments, statistical analysis, drafted the manuscript and both authors interpreted the results. Authors also read and approved the manuscript. A signed document has been filed in the journal archives.

\section{RESULTS}

Table 1 shows the mean concentrations $(\mu \mathrm{g} / \mathrm{g}$ dry weight) of iron (Fe), copper (Cu), zinc ( $\mathrm{Zn})$, cadmium (Cd) and lead $(\mathrm{Pb})$ in the kidneys of T. zillii, M. rume, R. ocellatus, C. gariepinus, Ch. nigrodigitatus and S. filamentosus. The kidneys of $R$. ocellatus had the highest levels of Fe $(2,92 \pm 0,10)$ and $\mathrm{Cd}(0,18 \pm 0,03)$, while those of Ch. nigrodigitatus $(2,78 \pm 0,02)$ and $T$. zillii $(0,03 \pm 0,02)$ had the lowest concentration of $\mathrm{Fe}$ and $\mathrm{Cd}$ respectively. T.zillii and M. rume accumulated $\mathrm{Cu}(3,01 \pm 0,02)$ and $\mathrm{Zn}(8,84 \pm 1,98)$ in their kidneys respectively more than the other fishes. Generally, the mean trace metal concentrations were not significantly different $(p>0,05)$ among the scaly and nonscaly fishes. The pattern of heavy metal accumulation in

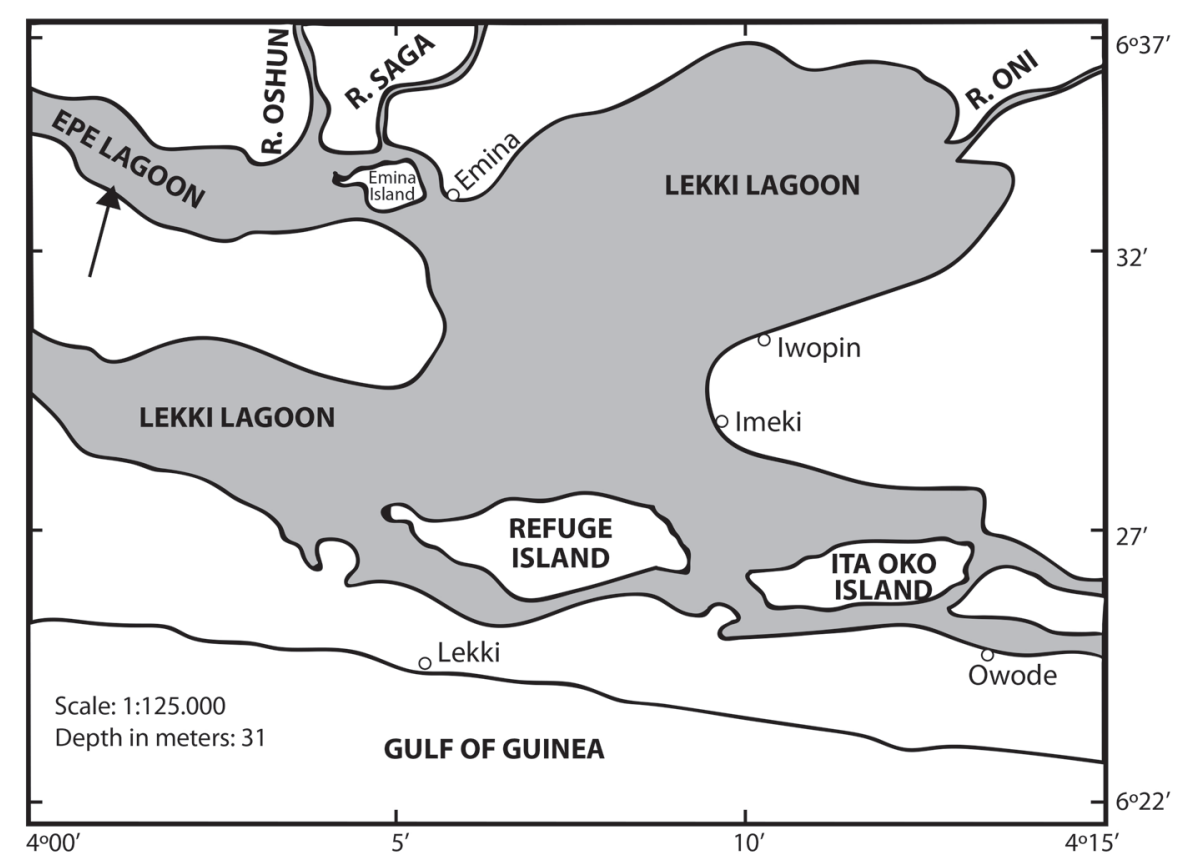

Fig. 1. Epe Lagoon (Akinsanya \& Otubanjo, 2006). 
order of decreasing concentration in the kidneys of both scaly and non-scaly fishes followed the same pattern as: $\mathrm{Zn}>\mathrm{Fe}>\mathrm{Cu}>\mathrm{Pb}>\mathrm{Cd}$ with $\mathrm{Zn}$ having the highest concentration in all the specimens. All the metals were detected in the kidneys of all the fishes investigated except cadmium in M. rume and lead in T. zillii and S. filamentosus, respectively that were below detectable limit.

A comparison of the mean concentrations of metals in the fish samples with FEPA (2003) and WHO (2008) standards in Table 1 shows that the concentrations of metals in fish specimens were below the maximum allowable limits in food fish. Of all the fishes examined, M. rume had the highest accumulation of all the heavy metals in ranking order: $\mathrm{Zn}>\mathrm{Cu}>\mathrm{Fe}>\mathrm{Pb}>\mathrm{Cd}$ slightly followed by $\mathrm{T}$. zillii with similar ranking as $M$. rume except $\mathrm{Pb}$ that was not detectable. The least contaminated fish was S. filamentosus with slightly different order of heavy metal ranking relative to the scaly fishes ( $M$. rume and $T$. zillii) i.e. $\mathrm{Zn}>\mathrm{Fe}>\mathrm{Cu}>\mathrm{Cd}>\mathrm{Pb}$. Generally, the pattern of heavy metal accumulation was: $M$. rume $>T$. zillii $>R$. ocellatus $>C h$. nigrodigitatus $>$ C. gariepinus $>$ S. filamentosus.

The mean value of $\mathrm{pH}(7,5 \pm 0,03)$ recorded in Epe Lagoon (Table 2) was within the range $\mathrm{pH} 6,9-9,5$ recommended by the Federal Environmental Protection Agency (FEPA, 2003) and $\mathrm{pH}$ 6-8 by the World Health Organisation (WHO, 2008). However, the dissolved oxygen content of the water $(9,0 \pm 0,02)$ and total alkalinity $(24,0 \pm 0,01)$ were above the values (dissolved oxygen: 3,0-5,0 mg/L and total alkalinity: 3,05-5,3mg/L) recommended by FEPA (2003). The ranking of heavy metals distribution in the water body was $\mathrm{Cu}(4,70)>\mathrm{Fe}(0,72)>\mathrm{Zn}$ $(0,13)>\mathrm{Pb}(0,007)>\mathrm{Cd}(0,006)$; almost a reverse of the pattern observed in the fish specimens (Table 1).

The bioconcentration factor (BCF) of Zn was generally high in all the species studied relative to the BCF recorded for other metals (Table 3). However, of the scaly fishes, only $R$. ocellatus showed a high BCF values in $\mathrm{Cd}$ and $\mathrm{Pb}$, while all the non-scaly fishes recorded high BCF values of the metals. The two other metals (Fe and $\mathrm{Cu}$ ) recorded low BCF values in both categories of fish species.

An overview of mean concentrations and/or ranges of heavy metals in some fishes in Nigeria and other parts of Africa in comparison with the present study showed that the concentrations of $\mathrm{Cu}$, Fe and $\mathrm{Zn}$ in Epe Lagoon are relatively two-fold higher than the concentrations in most parts of Nigeria and Africa (Table 4).

TABLE 1

Mean concentrations $(\mu \mathrm{g} / \mathrm{g})$ of heavy metals in the kidneys of scaly and non-scaly fishes from Epe Lagoon, Nigeria

\begin{tabular}{|c|c|c|c|c|c|c|c|c|}
\hline \multirow{3}{*}{$\begin{array}{l}\text { Heavy } \\
\text { metals }\end{array}$} & \multicolumn{6}{|c|}{ Fish species } & \multicolumn{2}{|c|}{ Standard value } \\
\hline & \multicolumn{3}{|c|}{ Scaly } & \multicolumn{3}{|c|}{ Non-scaly } & \multirow{2}{*}{$\begin{array}{l}\text { FEPA } \\
(2003)\end{array}$} & \multirow{2}{*}{$\begin{array}{l}\text { WHO } \\
(1989)\end{array}$} \\
\hline & T. zillii (+48) & M. rume $(+52)$ & R. ocellatus (+41) & C. gariepinus $(+54)$ & Ch. nigrodigitatus (+39) & S. filamentosus $\left({ }^{+} 41\right)$ & & \\
\hline $\mathrm{Fe}$ & $2,87 \pm 0,02$ & $2,89 \pm 0,04$ & $2,92 \pm 0,10$ & $2,86 \pm 0,07$ & $2,78 \pm 0,02$ & $2,84 \pm 0,05$ & $100 \mu \mathrm{g} / \mathrm{g}$ & $100 \mu \mathrm{g} / \mathrm{g}$ \\
\hline $\mathrm{Cu}$ & $3,01 \pm 0,02$ & $2,93 \pm 0,06$ & $2,68 \pm 0,15$ & $2,61 \pm 0,13$ & $2,72 \pm 0,09$ & $2,81 \pm 0,06$ & $1-3 \mu \mathrm{g} / \mathrm{g}$ & $30 \mu \mathrm{g} / \mathrm{g}$ \\
\hline $\mathrm{Zn}$ & $8,31 \pm 2,28$ & $8,84 \pm 1,98$ & $7,29 \pm 1,55$ & $7,23 \pm 0,12$ & $7,27 \pm 0,18$ & $7,09 \pm 0,07$ & $75 \mu \mathrm{g} / \mathrm{g}$ & $10-75 \mu \mathrm{g} / \mathrm{g}$ \\
\hline $\mathrm{Cd}$ & $0,03 \pm 0,01$ & BDL & $0,18 \pm 0,03$ & $0,12 \pm 0,05$ & $0,16 \pm 0,03$ & $0,13 \pm 0,02$ & 2,0ppm & $1 \mu \mathrm{g} / \mathrm{g}^{*}$ \\
\hline $\mathrm{Pb}$ & $\mathrm{BDL}$ & $0,03 \pm 0,01$ & $0,27 \pm 0,06$ & $0,28 \pm 0,02$ & $0,31 \pm 0,06$ & $\mathrm{BDL}$ & 2,0ppm & $2 \mu \mathrm{g} / \mathrm{g}^{*}$ \\
\hline
\end{tabular}

$\mathrm{BDL}=$ below detectable limit; ${ }^{*} \mathrm{WHO}(2008){ }^{+}$Number of specimens.

TABLE 2

Physico-chemical parameters and mean concentration of heavy metals in water samples from Epe Lagoon, Nigeria

\begin{tabular}{lccc}
\multicolumn{1}{c}{ Parameter/Heavy metal } & Concentration (Mean \pm SD, mg/L) & \multicolumn{2}{c}{ Standard specification } \\
Dissolved oxygen & $9,0, \pm 0,02$ & $3,0-5,0 \mathrm{mg} / \mathrm{L}$ & WHO (1997) \\
$\mathrm{pH}$ & $7,5 \pm 0,03$ & $6,5-9,5$ & - \\
Alkalinity & $24,0 \pm 0,01$ & $3,05-5,3 \mathrm{mg} / \mathrm{L}$ & $6,5-9,5$ \\
Iron (Fe) & $0,72 \pm 0,01$ & $0,3 \mathrm{mg} / \mathrm{L}$ & - \\
Copper (Cu) & $4,70 \pm 0,03$ & $<1 \mathrm{mg} / \mathrm{L}$ & - \\
Zinc (Zn) & $0,13 \pm 0,02$ & $20 \mathrm{mg} / \mathrm{L}$ & $1,00 \mathrm{mg} / \mathrm{L}$ \\
Cadmium (Cd) & $0,006 \pm 0,01$ & $<1 \mathrm{mg} / \mathrm{L}$ & $5,00 \mathrm{mg} / \mathrm{L}$ \\
Lead $(\mathrm{Pb})$ & $0,007 \pm 0,02$ & $<1 \mathrm{mg} / \mathrm{L}$ & $0,05 \mathrm{mg} / \mathrm{L}$ \\
\hline
\end{tabular}


TABLE 3

Bioconcentration factors of heavy metals in the kidneys of fish species in Epe Lagoon, Nigeria

\begin{tabular}{|c|c|c|c|c|c|}
\hline \multicolumn{6}{|c|}{ Heavy metal Bioconcentration factor } \\
\hline Fish species & $\mathrm{Fe}$ & $\mathrm{Cu}$ & $\mathrm{Zn}$ & $\mathrm{Cd}$ & $\mathrm{Pb}$ \\
\hline T. zillii & $33,99 \pm 0,02^{\mathrm{a}}$ & $0,64 \pm 0,01^{\text {a }}$ & $63,92 \pm 1,12^{b}$ & $5,00 \pm 0,63^{b}$ & $0,00 \pm 0,00^{\mathrm{a}}$ \\
\hline M. rume & $4,01 \pm 0,06^{a}$ & $0,62 \pm 0,02^{a}$ & $68,00 \pm 2,10^{\mathrm{a}}$ & $0,00 \pm 0,00^{a}$ & $4,43 \pm 0,31^{b}$ \\
\hline R. ocellatus & $4,06 \pm 0,07^{a}$ & $0,57 \pm 0,01^{\mathrm{a}}$ & $56,08 \pm 1,98^{a}$ & $30,00 \pm 0,83^{e}$ & $38,57 \pm 1,05^{c}$ \\
\hline C. gariepinus & $33,97 \pm 0,04^{a}$ & $0,55 \pm 0,02^{\mathrm{a}}$ & $55,62 \pm 1,67^{a}$ & $20,00 \pm 0,66^{c}$ & $40,00 \pm 0,96^{c}$ \\
\hline Ch. nigrodigitatus & $33,86 \pm 0,03^{a}$ & $0,58 \pm 0,01^{\text {a }}$ & $55,92 \pm 1,73^{a}$ & $26,67 \pm 0,43^{d}$ & $44,29 \pm 1,10^{d}$ \\
\hline S. filamentosus & $3,94 \pm 0,04^{\mathrm{a}}$ & $0,59 \pm 0,02^{\mathrm{a}}$ & $54,54 \pm 1,55^{\mathrm{a}}$ & $21,67 \pm 0,41^{c}$ & $0,00 \pm 0,00^{\mathrm{a}}$ \\
\hline
\end{tabular}

Values with the same superscripts are not significantly $(p>0,05)$ different.

TABLE 4

Comparison of mean concentrations and/or ranges of heavy metals in some fishes in Nigeria and other parts of Africa

\begin{tabular}{|c|c|c|c|c|c|c|}
\hline \multirow{2}{*}{ Location/Country } & \multicolumn{5}{|c|}{ Heavy metal / Concentration $(\mu \mathrm{g} / \mathrm{g})$} & \multirow{2}{*}{ Reference } \\
\hline & $\mathrm{Fe}$ & $\mathrm{Cu}$ & $\mathrm{Zn}$ & $\mathrm{Cd}$ & $\mathrm{Pb}$ & \\
\hline Nigeria: Epe Lagoon & $2,78-2,92(2,79)$ & $2,61-3,01(2,79)$ & $7,09-8,84(7,67)$ & $0,03-0,18(0,10)$ & BDL-0,31 $(0,18)$ & This study \\
\hline Imo River & 0,02 & nd & 0,05 & $\mathrm{nr}$ & nd & Nauen (1983) \\
\hline Aba River & 0,30 & 0,14 & 1,50 & $\mathrm{nr}$ & 0,01 & Nauen (1983) \\
\hline Kainji Lake & $\mathrm{nr}$ & $0,16-2,98(1,50)$ & $13,64-36,78$ & $0,03-0,21$ & BDL-1,12 & Jimoh et al. (2004) \\
\hline Aba River & $0,30-0,35$ & $0,03-0,14$ & $1,50-2,50$ & $\mathrm{nr}$ & $0,01-0,02$ & Ubalua et al. (2007) \\
\hline Taylor's creek & $\mathrm{nr}$ & $\mathrm{nr}$ & $2,54-3,59$ & $0,02-0,04$ & $0,38-0,87$ & Agbozu et al. (2007) \\
\hline Ogun River catchment & $0,16-0,25^{*}$ & $\mathrm{nr}$ & $0,20-0,24^{*}$ & $0,002-0,003^{*}$ & $0,04-0,05^{*}$ & Adeniyi et al. (2008) \\
\hline Alau Dam, Maiduguri & $0,29-0,39$ & $0,04-0,63$ & $0,15-0,52$ & $0,09-0,49$ & $0,12-0,53$ & Dimari et al. (2008) \\
\hline Lake Chad, Maiduguri & $0,10-0,34$ & $0,01-0,65$ & $0,11-0,62$ & $0,01-0,22$ & $0,01-0,32$ & Akan et al. (2009) \\
\hline Aladja River, Warri & $0,80-18,01$ & $\mathrm{nr}$ & $1,04-10,80$ & $<0,01-0,20$ & $0,01-2,40$ & Nduka et al. (2010) \\
\hline Ikere Gorge, Oyo & $0,192-0,754$ & $0,008-0,039$ & $0,227-0,711$ & nd & $0,127-1,170$ & Adeosun et al. (2010) \\
\hline Epe Lagoon & $0,10-13,30$ & nd & $0,16-1,95$ & nd & nd & Olowu et al. (2010) \\
\hline Other Africans: Egypt & $\mathrm{nr}$ & 1,65 & 4,27 & 0,004 & 0,07 & El Nabawi et al., (1987) \\
\hline Senegal & $\mathrm{nr}$ & 0,73 & 4,55 & $<0,10$ & 0,5 & $\mathrm{Ba}(1988)$ \\
\hline Cote d'Ivoire & $\mathrm{nr}$ & 0,80 & 4,86 & $<0,25$ & nd & Metongo (1988) \\
\hline Cameroon & $\mathrm{nr}$ & 0,75 & 5,55 & $<0,10$ & 1,83 & Mbome (1988) \\
\hline Cameroon & $\mathrm{nr}$ & $\mathrm{nr}$ & $11,61-23,50$ & $1,10-18,50$ & $2,62-13,20$ & Ali et al. (2010) \\
\hline Ghana & $\mathrm{nr}$ & 0,46 & 4,63 & $<0,10$ & 0,36 & Mbome (1988) \\
\hline Ghana & 11,74 & 6,19 & 11,1 & 0,19 & 0,66 & Tay et al. (2008) \\
\hline $\begin{array}{l}\text { Western and Central African } \\
\text { inland waters }\end{array}$ & $\mathrm{nr}$ & $0,18-0,70$ & $3,0-5,6$ & $0,03-0,19$ & $0,43-0,48$ & Biney et al. (1994) \\
\hline Northern African Inland waters & $\mathrm{nr}$ & $1,77-3,70$ & $7,4-8,0$ & $0,004-0,15$ & 0,67 & Biney et al. (1994) \\
\hline Lake Victoria, Tanzania & $\mathrm{nr}$ & $0,07^{* *}$ & $8,8^{* *}$ & $4,67^{* *}$ & $0,13^{* *}$ & Mbome (1988) \\
\hline Lake Awassa, Ethiopia & $\mathrm{nr}$ & 797 & 115,9 & 4,9 & 42,3 & Aweke \& Taddese (2004) \\
\hline Lake of $\mathrm{Be}$, Togo & $\mathrm{nr}$ & $1,0-5,0$ & $15,4-20,2$ & $<0,05$ & $0,6-2,8$ & Bawa et al. (2007) \\
\hline
\end{tabular}

* Concentration in mg/kg; ${ }^{* *}$ Concentration in $\mathrm{mg} / \mathrm{g} ; \mathrm{nr}$ Not reported; nd Not determined.

\section{DISCUSSION}

The increased bioaccumulation of metals, as a result of anthropogenic activities, industrialization and urbanization, in both aquatic and terrestrial biota has been a serious public health concern worldwide. This is because when their levels go beyond tolerable limit they become toxic (Koller, Brown, Spurgeon, \& Levy, 2004). With over $60 \%$ of Nigerian industries cited in Lagos State (Olowu et al., 2010), industrial effluents containing heavy metals are 
regularly being discharged into the aquatic ecosystems. The bioaccumulation and biomagnification of these metals in aquatic biota through the food chain could lead to hazardous level even when the level of exposure is low. Hence, environmental concerns are normally focused on the State (Olowu et al., 2010) and elevated levels of trace metals in the aquatic ecosystems. The state of heavy metal contamination s has been well documented in the last decades (Farmakin \& Thomaidis, 2008). The adverse effects of heavy metals due to their highly persistent and non-biodegradable nature have also been well documented (Tsuchiya et al., 2008; Matthews \& Fisher, 2008). In Nigeria, the flesh/tissue is the most consumed part of fish, though in some riverine areas where fishes are never de-gutted during processing; the organs in situ e.g. gills, kidneys, etc. are also eaten. Therefore, the concentration of metals in the kidneys of fish species was investigated in this present study, with the understanding that this may lead to adverse health effects in human subject when the level of such metal is in excess.

The levels of all the heavy metal concentrations obtained from Epe Lagoon water samples were within the WHO specifications. This corroborates the findings of Benedict, Oladapo, and Emmanuel (1991), Adeniyi and Yusuf (2007) and Adefemi et al. (2008), who reported that the level of heavy metal determined in the samples of Epe and Badagry Lagoon were lower than those reported in the sediment. The higher concentration of copper $(4,7 \pm 0,03)$ in the water samples from Epe Lagoon than the standard specification (<1 mg/L) by FEPA (2003) and WHO (1997) may be as a result of heavy microbial contamination of the water body (Numako \& Nakai, 1995; Bernard et al., 2009). The findings showed higher value of dissolved oxygen in the water sample $(9,0 \pm 0,02)$ than the standard specification (3,0-5,0mg/L; FEPA 2003). Contrary to the aforementioned, however, the bioconcentration factor of copper was low. This may be indicative that penetration of toxicants into the aquatic organisms may be influenced by several complex factors, such as food foraging behaviour and food habits of the organism, food availability, source of metals, metal detoxifying proteins in the body of the organism and metabolic rate of the organism, etc., which should be further investigated.

Fe is an essential element but has no health-based guideline value, however, its high concentrations in water give rise to consumer complaints. Carine and Lawrence (1977) reported that higher concentration of Fe than the permissible limit leads to cirrhosis and its deposition in the lungs, pancreas and heart. Strause and Saetman (2000) also noted that Fe is associated with serious heart disease and tumour induction, pancreatic dysfunction and diabetics. Copper and $\mathrm{Zn}$ have been known to be essential micronutrients for growth of organisms even at low concentration. Cadmium is one of the most toxic heavy metals known to be carcinogenic in humans (Goering, Waalkes, \& Klassen, 1994) and capable of inducing hepatic, renal and testicular damage. Lead is not an essential element but could be very toxic even at low concentration. It may impair renal function, RBC production, the nervous system and causes blindness. The high mean Fe concentration recorded in $R$. ocellatus than in other fishes could be due to differences in feeding habits with $R$. ocellatus being exposed to more and richer dietary sources of Fe in the water body. The concentration of Fe in all the species examined which were lower than the FEPA (2003) and WHO (2008) guideline values of $100 \mu \mathrm{g} / \mathrm{g}$ respectively is suggestive of the fact that, with respect to Fe, these fish species in Epe Lagoon may be safe for human consumption. The risk of bioaccumulation over a period of time is, however, inevitable if its rate of uptake is higher than its elimination. The range and /or mean concentrations of $\mathrm{Fe}$ in all the fishes examined (Table 4) in this study was relatively higher than those of other fishes reported in some water bodies in Nigeria (Akan, Abdul Rahman, Sodipo, \& Akan, 2009; Adeosun, Omoniyi, Akegbejo-Samsons, \& Olujimi, 2010). However, those reported in previous studies in Ogun River catchment area, Lagos, Nigeria (Adeniyi, Yusuf, \& Okedeyi, 2008) and Aladja River, Warri (Nduka, Orisakwe, \& Okerulu, 2010) were higher than the value (Mean $=2,79 \mu \mathrm{g} / \mathrm{g}$ ) reported in this study. Comparing the value $(2,79 \mu \mathrm{g} / \mathrm{g})$ with those reported from previous studies in African sub-region, it was less than the value $(11,74 \mu \mathrm{g} / \mathrm{g})$ reported in Ghanaian coastal and inland waters (Tay, Asmah, \& Biney, 2008).

The mean concentration of $\mathrm{Cu}$ obtained for each of the fish sample that was found to be below the $1-3 \mu \mathrm{g} / \mathrm{g}$ (FEPA, 2003) and 30 $\mu \mathrm{g} / \mathrm{g}$ (WHO, 2008) prescribed limit for $\mathrm{Cu}$ in food fish, indicates that all the fishes were free from Cu-related toxicity and are fit for human consumption. The mean concentration of $\mathrm{Cu}$ in this study was higher than the mean/range of values reported by Ubalua et al. (2007) from Aba River, Nigeria, Akan et al. (2009) from Lake Chad and Adeosun et al. (2010) from Ikere Gorge, Oyo. This might be due to greater anthropogenic pressure on the lagoon which resulted in increased $\mathrm{Cu}$ load discharged in to the lagoon from adjoining industries. Lagos State where Epe lagoon is located is generally characterized by many industries as opposed to where Aba River, Lake Chad and Ikere Gorge are situated, respectively. While the level of the trace metal in all the fishes examined was within the low to medium range of those reported for fishes in Northern African inland waters (Biney et al., 1994), the level was greater than those for some fish species in Egypt (El-Nabawi, 1987), Senegal 
(Ba, 1988), and Western and Central African inland waters (Biney et al., 1994); but lower than the values reported in Tanzania (Kishe \& Machiwa, 2003), Ethiopia (Aweke \& Taddese, 2004) and Ghana (Tay et al., 2008). This may not be strange as the concentrations of heavy metals in the same or different species is bound to vary to a large extent depending on the location of sampling sites.

Zn have been reported to have low toxicity in man, its prolonged consumption in large doses can result in health complication e.g. fatigue, dizziness, neutropenia, vomiting and diarrhoea (Nduka et al., 2010). Zn contamination in the lagoon could be attributed to the discharge of contaminants containing high load of $\mathrm{Zn}$ from sewage effluents. Domestic wastes, animal and human faeces from riparian communities along the bank of the lagoon are discharged into the waterbody indiscriminately. Thus, the high concentration of $\mathrm{Zn}$ in all the fish species in relation to other heavy metals could be as a result of uptake of Zn-laden sewage effluents washed into the lagoon during feeding. Similar observation was made by Monday and Nsikak (2007) in Imo river; Nnaji, Uzairu, Harrison, and Balarabe (2007) in River Gelma, Zaria and Ibrahim and Sa'id (2010) in Jakara River and Kusalla dam, Kano State, Nigeria, respectively. The estimated level of $\mathrm{Zn}(7,67 \mu \mathrm{g} / \mathrm{g})$ in this study was below the $\mathrm{Zn}$ prescribed standard safe limits of $75 \mu \mathrm{g} / \mathrm{g}$ for food fish; thus implying that the fishes do not constitute any health risk upon their consumption. The estimated level was higher than the average measured level in the fishes of Taylor creek, Lake Chad (Akan et al., 2009); Ikere Gorge (Adeosun, 2010) and Epe lagoon (Olowu et al., 2010); but lower than those recorded in fishes from Aladja River (Nduka et al., 2010) and Ogun River catchment area (Adeniyi et al., 2008). This value is almost comparable to those reported in other parts of Africa (Biney et al., 1994) but lower than those recorded in some fishes in Ghana (Tay et al., 2008) and Cameroun (Ali, Ahmadou, Mohamadou, Saidou, \& Tenin, 2010). The relatively higher mean level of $Z n$ reported in this study as compared to that reported in the same lagoon by Olowu et al. (2010) could be due to differences in the input of organic matter deposited in the lagoon.

The range of concentrations of $\mathrm{Cd}(0,03 \pm 0,01$ $0,18 \pm 0,03)$ in the fish species was below the threshold limit prescribed by WHO (1989) and 0,5 $\mu \mathrm{g} / \mathrm{g}$ threshold considered harmful to fish. Therefore, $\mathrm{Cd}$ does not appear to present itself as toxic contaminant that could cause hazard to fish in the lagoon and fish consumers. The ranges of values are comparable to those documented in other fishes from Nigeria (Bawa, Djaneye-Boundjou,
Boyode, \& Assih, 2007). Similarly, the values are comparable to those recorded for some fishes in other parts of Africa (El Nabawi, 1987; Ba, 1988; Metongo, 1988; Biney et al., 1994; Tay et al., 2008). The values are; however, lower than those in fishes from Lake Victoria in Tanzania, Lake Awassa, Ethiopia (Aweke \& Taddese, 2004) and Cameroon (Ali et al., 2010). Bioaccumulation of $\mathrm{Pb}$ in fish samples exceeding $0,5 \mu \mathrm{g} / \mathrm{g}$ is considered potentially inhibitory to fish reproduction and survival. The range of values (BDL $-0,31 \pm 0,06)$ obtained in the fish species investigated were below this level $(0,5 \mu \mathrm{g} / \mathrm{g})$ of concern. The values (BDL - $0,31 \pm 0,06$ ) were also below WHO (1989) guideline of $2 \mu \mathrm{g} / \mathrm{g}$; thus indicating that the concentration of $\mathrm{Pb}$ in the fish samples do not pose any threat upon their consumption. The mean $\mathrm{Pb}$ concentration for the fish species in this study $(0,18 \mu \mathrm{g} / \mathrm{g})$ compare favourably with those reported from previous studies in Nigeria (Jimoh \& Haruna, 2007; Ubalua et al., 2007; Akan et al., 2009), as it fell within the range of concentration earlier reported, except those of Adeniyi et al. (2008) and Dimari, Abdulkarim, Akan, and Garba (2008) that are relatively higher. The differential sources of $\mathrm{Pb}$ to different aquatic environments may have accounted for the difference in concentrations obtained. This reason may also be advanced for other metals investigated.

The non-significance difference $(p>0,05)$ in mean trace metal concentrations among the scaly and nonscaly fishes in this study is suggestive of the fact that accumulation of metals was seemingly not determined by the nature of skin. The main mode of metal absorption, therefore, appears to be through dietary uptake. In conclusion, the kidneys of T. zillii, M. rume, R. ocellatus, $C$. gariepinus, Ch. nigrodigitatus and $S$. filamentosus contain some quantities of metals, although, the concentrations are still within the safe limit for consumption. Given the socio-economic importance of Epe Lagoon to the inhabitants of Epe and its environs and the potential health hazards the increase levels of these metals could portend, close monitoring of these metals in the fishes and the lagoon is important in order to ensure safety of fish consumers in the area. Dumping of municipal wastes along the course of the lagoon should be discouraged; so as to avoid the entry of these metals into the waterbody.

\section{ACKNOWLEDGEMENTS}

We thank the technical assistance of Kale O. E of the Department of Pharmacology and Benjamin S. Carson School of Medicine, Babcock University, Nigeria. 


\section{REFERENCES}

Adefemi, S.O., Asaolu, S.S., \& Olaofe, O. (2008). Determination of Heavy Metals in Tilapia mossambicuis Fish, Associated Water and Sediment from Ureje Dam in South-Western Nigeria. Research Journal of Environmental Sciences, 2(2), 151-155. DOI: 10.1007/s10661-007-9780-5

Adeniyi, A.A., \& Yusuf, K.A. (2007). Determination of heavy metals in fish tissues, water and bottom sediments from Epe and Badagry lagoons, Lagos, Nigeria. Environmental Monitoring and Assessment, 37,451-458

Adeniyi, A.A., Yusuf, K.A., \& Okedeyi, O. O. (2008). Assessment of the exposure of two fish species to metals pollution in the Ogun river catchments, Ketu, Lagos, Nigeria. Environmental Monitoring and Assessment, 137, 451-458. DOI: 10.1007/s10661-007-9780-5

Adeosun, F.I., Omoniyi, I.T., Akegbejo-Samsons, Y., \& Olujimi, O.O. (2010). Heavy metal contamination of Chrysichthys nigrodigitatus and Lates niloticus in Ikere Gorge, Oyo state, Nigeria. African Journal of Biotechnology, 9(39), 6578-6581.

Agbozu, I.E., Ekweozor,I.K.E. \& Opuene, K. (2007). Survey of heavy metals in the catfish (Synodontis clarias). International Journals of Environmental Science and Technology, 4(1), 93-97.

Alam, M.G., Allinson, G., Stagnitti, F., Tanaka, A., \& Westbrooke, M. (2002). Arsenic contamination in Bangladesh groundwater: a major environmental and social disaster. International Journal of Environmental Health Research, 12, 235-253.

Akan, J.C., Abdul Rahman, F.I., Sodipo, O.A., \& Akan, D.U. (2009). Bioaccumulation of some heavy metals of six fresh water fishes caught from Lake Chad in Doron Buhari, Maiduguri, Borno, State, Nigeria. Journal of Applied Sciences in Environmental Sanitation, 4(2), 103-114.

Akueshi, E.U., Oriegie, E., Ocheakiti, N., \& Okunsebor. S. (2003). Levels of some heavy metals in fish from mining lake on the Jos Plateaus, Nigeria. African Journal of Natural Science, 6, 82-86

Akinsanya, B., \& Otubanjo, O.A. (2006). Helminth Parasite of Clarias gariepinus (Clariidae) in Lekki Lagoon, Lagos. Revista de Biología Tropical, 54, 93-99.

Ali, A., Ahmadou, D., Mohamadou, B.A., Saidou, C., \& Tenin, D. (2010). Determination ofminerals and heavy metals in water, sediments and three fis species (Tilapianilotica, Silurus glanis and Arius parkii)from Lagdo lake, Cameroun. Journal of Fisheries International, 5(3), 54-57. DOI: 10.3923/jfish.2010.54.57

Aweke, K., \& Taddese W. (2004), Distribution of trace elements in muscle and organs of Tilapia, Oreochromis niloticus, from lakes Awassa and Ziway, Ethiopia; Bulletin of the Chemical Society of Ethiopia, 18(2), 119-130.

Ba, D. (1988). Analyse des contaminants chez les organismes marins d'importance commerciale dans les eaux côtières du Sénégal. Report presented to Second Workshop of participants in the Joint FAO/IOC/WHO/IAEA/UNEP Project on pollution in the marine environment of the west and central African region (WACAF/2-First Phase), Accra, Ghana. Paris, France: IOC of Unesco.

Barbier, O., Jacquillet, G., Tauc, M., Cougnon, M., \& Poujeol, P. (2005). Effect of heavy metals on, and handling by, the kidney. Nephron Physiology, 99, 105-110

Bawa, L.M., Djaneye-Boundjou, G., Boyode, B.P., \& Assih, B.T. (2007). Water quality evaluation from Lomé's lagoon: Effects on Heavy metal contamination on fishes. Journal of Applied Sciences and Environmental Management, 11(4), 33-36.

Benedict, C.O.O., Oladapo, A.A., \& Emmanuel, A.A. (1991). Heavy metals in Lagos Lagoon sediment. International Journal of Environmental Studies, 37(1\&2), 35-41.

Bernard, L., Maron P.A., Mougel C., Nowak V., Lévêque J., Marol, C., ... Ranjard, L. (2009). Contamination of Soil by Copper Affects the Dynamics, Diversity, and Activity of Soil Bacterial Communities Involved in Wheat Decomposition and Carbon Storage. Applied and Environmental Microbiology, 75(23), 7565-7569, DOI: 10.1128/AEM.00616-09

Biney, C., Amuzu, A.T., Calamari, D., Kaba, N., Mbome, I.L., Naeve, H.C.F., ... West, W.Q.B. (1994). Review of heavy metals in the African aquatic environment. Ecotoxicology and Environmental Safety, 28, 134-159, DOI: 10.1006/ eesa.1994.1041

Carine, N.H., \& M.R. Lawrence (1977). Normal and therapeutic nutrition ( $5^{\text {th }}$ ed.). New York, USA: MacMillan Publishers.

Chatterjee, A., Jurgenson, C.T., Schroeder, F.C., Ealick, S.E., \& Begley, T.P. (2006). Thiamin biosynthesis in eukaryotes: characterization of the enzyme-bound product of thiazole synthase from Saccharomyces cerevisiae and its implications in thiazole biosynthesis. Journal of the American Chemical Society, 128, 7158-7159. DOI: 10.1021/ja061413o

Dimari, G.A., Abdulkarim, F.I., Akan, J.C., \& Garba, S.T. (2008). Metal concentrations in Tissues of Tilapia galier, Clarias lazera, and Osteoglosidae caught from Alau Dam, Maiduguri, Borno State. Nigeria. American Journal of Environmental Sciences, 4(4), 473-379.

El Nabawi, A., Heinzow, B., \& Kruse, H. (1987). As, Cd, Cu, Pb, $\mathrm{Hg}$ and $\mathrm{Zn}$ in fish from the Alexandria Region, Egypt. Bulletin of Environmental Contamination and Toxicology, 39, 889-97. DOI: 10.1007/BF01855871

FAO (Food and Agriculture Organziation). (1989). Evaluation of certain food additives and the contaminants mercury, lead and cadmium. Geneva, Switzerland: World Health Organization Technical Report Series.

Farmakin, E.G., \& Thomaidis, N.S. (2008). Current Status of the Metal Pollution of the Environment of Greece - A Review. Global Nest Journal, 10(3), 366-375.

Farombi, E.O., Adelowo, O.A., \& Ajimoko, Y.R. (2007). Biomarkers of oxidative stress and heavy metal levels as indicators 
of environmental pollution in African Cat fish (Clarias gariepinus) from Nigeria Ogun River. International Journal of Environmental Research and Public Health, 4(2), 158165. DOI: 10.3390/ijerph2007040011

FEPA. (Federal Environmental Protection Agency). (2003). Guidelines and Standards for Environmental Pollution Control in Nigeria. Nigeria: FEPA.

Gilbert, J.J., (1994). Susceptibility of planktonic rotifers to a toxic strain of Anabaena flos-aquae. Limnology and Oceanography, 39, 1286-1297. DOI: 10.4319/ lo.1994.39.6.1286

Goering, P.L., Waalkes, M.P., \& Klassen, C.D. (1994). Toxicology of cadmium. In R.A. Goyer \& M.G. Cherian (Eds.), Handbook of Experimental Pharmacology: Toxicology of Metals, Biochemical Effects (pp.115, 189-214). Springer-Verlag: New York.

Ibrahim, S., \& Sa'id, H. (2010). Heavy metals load in tilapia species: a case study of Jakara river and Kusalla dam, Kano state, Nigeria. Bayero Journal of Pure \& Applied. Science, 3. DOI: 10.4314/bajopas.v3i1.58721

Jimoh, S.O., \& Haruna, E.A. (2007). Contribution of non-timber forest products to house food security and income around Onigambari forest reserve, Oyo State, Nigeria. Journal of Environmental Extension, 6, 28-33. DOI: 10.4314/jext.v6i1.2758

Jimoh, L.A., Adebayo, M.A.B., \& Amood, I.A. (2005) Evaluation of the body burdens of heavy metals in five commercially important fishes from different locations in Kainji Lake. In 19th Annual Conference of the Fisheries Society of Nigeria (FISON, pp. 702-709), Ilorin, Nigeria.

Kalay, M., Ay, O., \& Canli, M. (1999). Heavy metal concentrations in fish tissues from the northeast Mediterranean Sea. Bulletin of Environmental Contamination and Toxicology, 63, 673-681, DOI: 10.1007/s001289901033.

Kishe, M.A., \& Machiwa, J.F. (2003). Distribution of heavy metals in sediments of Mwanza Gulf of Lake Victoria, Tanzania. Environment International, 28, 619-625. DOI: 10.1016/ S0160-4120(02)00099-5

Koller, K., Brown. T., Spurgeon, A., \& Levy, L. (2004). Recent developments in low-level lead exposure and intellectual impairment in children. Environmental Health Perspectives, 112, 987-994. DOI: 10.1289/ehp.6941

Labonne, M., Ben Othman, D., \& Luck, J.-M. (2001). Pb isotopes in mussels as tracers of metal sources and water movements in a lagoon (Thau Basin, S. France). Chemical Geology 181(1-4), 181-191. DOI: 10.1016/

Lagler, K.F., Bardach, J.E., Miller, R.R., \& May Passino, D.R. (1977). Ichthyology ( $2^{\text {nd }}$ ed.). New York: John Wiley \& Sons.

Lawani, S.A., \& Alawode, J.A. (1996). Concentrations of lead and mercury in River Niger and its fish at Jebba. Bioscience Research Communication, 8(1), 47-49

Mbome, I.L. (1988). Heavy metals in marine organisms from Limbe and Douala. Report presented to Second Workshop of participants in the Joint FAO/IOC/WHO/IAEA/UNEP Project on pollution in the marine environment of the West and Central African Region (WACAF/2-First Phase), Accra, Ghana, 13-17 June 1988. IOC of UNESCO, Paris, France.

Metongo, B.S. (1988). Metaux lourds dans les organismes marins - Côte d'Ivoire. Report presented to Second Workshop of participants in the Joint FAO/IOC/WHO/IAEA/UNEP Project on pollution in the marine environment of the west and central African region (WACAF/2-First Phase), Accra, Ghana, 13-17 June 1988. Paris, France: IOC of Unesco.

Monday, U.E., \& Nsikak, U.B. (2007). Cadmium, copper, lead and zinc tissue levels in Bonga shad (Ethmalosa Fimbriata) and Tilapia (Tilapia guineensis) caught from Imo River, Nigeria. American Journal of Food Technology, 2(1), 4854. DOI: 10.3923/ajft.2007.48.54

More, T.G., Rajput, R.A., \& Bandela, N.N. (2003). Impact of heavy metals on DNA contents in the whole body ffreshwater bivalve, Lamellidens marginalis. Polluton Research 22(4), 605-611

Nduka, J.K., Orisakwe, O.E., \& Okerulu, I.O. (2010). Heavy Metal Levels in Muscles of Some Fish Species from Aladja River; Warri, Nigeria: A Public Health Concern. Advances Environmental Biology, 4(5), 125-130.

Nnaji, J., Uzairu, A., Harrison, G.F.S., \& Balarabe, M.L. (2007). Evaluation of cadmium, chromium, copper, lead and zinc concentrations in the fish head/viscera of Oreochromis niloticus and Synodontis schall of River Galma, Zaria, Nigeria. Electronic Journal of Environmental, Agricultural and Food Chemistry, 6(10), 2420-2426.

Numako, C., \& Nakai, I. (1995). Studies of some precipitation and coloration reaction used in analytical chemistry. Physica B. Condensed Matter, 208, 387-388, DOI: 10.1016/0921-4526(94)00706-2

Nwani, C.D., Lakra, W.S., Nagpure, N.S., Kumar, R., Kushwaha, B., \& Srivastava, S.K. (2010). Mutagenic and genotoxic effects of carbosulfan in freshwater fish (Bloch) using micronucleus assay and alkaline single-cell gel electrophoresis. Food and Chemical Toxicology, 48(1), 202-208, DOI: 10.1016/j.fct.2009.09.041

Mansour, S.A., \& Sidky, M.M. (2002). Ecological studies 3: Heavy metals contaminating water and fish from Fayoum Governorate, Egypt. Food Chemistry 78(1), 15-22. DOI: 10.1016/s0308-8146(01)00197-2

Nauen, C.E. (1983). Compilation of legal limits for hazardous substances in fish and fishery products. FAO Fisheries Circular. 764. Rome, Italy: FAO.

Okoye, B.C.O. (1991). Heavy metals and organisms in the Lagos Lagoon. International Journal of Environmental Studies, 37, 285-292, DOI: 10.1080/00207239108710641

Olowu, R.A., Ayejuyo, O.O., Adewuyi, G.O., Adejoro, I.A., Denloye, A.A.B., Babatunde, A.O., \& Ogundajo, A.L. (2010). Determination of Heavy Metals in Fish Tissues, 
Water and Sediment from Epe and Badagry. E-Journal of Chemistry, 7(1), 215-221. DOI: 10.1155/2010/676434

Omoregie, E., Okoronkwo, M.O., Eziashi, A.C., \& Zoakah, A.I. (2002). Metal concentrations in water column, benthic macroinvertebrates and tilapia from Delimi River, Nigeria. Journal of Aquatic Sciences, 17(1), 55-59, DOI: 10.4314/jas.v17i1.19911

Ovuru, S.S., \& Alfred-Ockiya, J.F. (2001). Occurrences of trace metals in Penaeus natialis (Decapoda: Penaedae) from Brass river. Global Journal of Pure and Applied Sciences, 7(4), 637-640. DOI: 10.4314/gjpas.v7i4.16301

Owolabi, O.D. (2008). The dietary habits of the upside-down catfish, Synodontis membranaceus (Osteichthyes: Mochokidae) in Jebba Lake, Nigeria. Revista de Biologia Tropical, 56(2), 931-936.

Sarnowski, P. (2003). The effect of metals on yolk sac resorption and growth of starved and fed common carp (Cyprinus carpio) larvae. Acta Scientiarum Polonorum Piscaria, 2, 227-236.

Sharpe, P.T. (2001). Fish scale development: Hair today, teeth and scales yesterday? Current Biology, 11(18), R751-R752, DOI: 10.1016/S0960-9822(01)00438-9

Strause, E.L., \& Saetman, P. (2000). Trace mineral interactions. Department of Biology, University of California at San Diego.

Tay, C., Asmah, R., \& Biney, C.A. (2008). Trace metal concentrations in commercially important fishes from some coastal and inland waters in Ghana. West African Journal of Applied Ecology, 13(1), 27-38. DOI: 10.4314/wajae. v13i1.40579
Tsuchiya, T., Yamada, K., Minoura, K., Miyamoto, K., Usami, Y., Kobayashi, T., \& Tsujibo, H. (2008). Purification and determination of the chemical structure of the tyrosinase inhibitor produced by Trichoderma viride strain H1-7 from a marine environment. Biological and Pharmaceutical Bulletin, 31(8), 1618-1620 DOI:10.1248/bpb.31.1618

Ubalua, A.O., Chijioke, U.C., \& Ezeronye, O.U. (2007). Determination and assessment of heavy metal content in fish and shellfish in Aba River, Abia State, Nigeria. KMITL Science and Technology Journal, 7(1), 16-23.

Vinodhini, R., \& Narayanan, M. (2008). Bioaccumulation of heavy metals in organs of fresh water fish Cyprinus carpio (Common carp). International Journal of Environmental Science and Technology, 5(2), 179-182. DOI: 10.1007/ BF03326011

WHO (World Health Organization). (1989). Heavy metals-environmental aspects. Environment Health Criteria No. 85. Geneva, Switzerland: World Health Organization.

WHO. (World Health Organization). (1997). Guidelines for drinking-water quality (Vol. 2), Health criteria and other supporting information ( $2^{\text {nd }}$ ed.). Geneva, Switzerland: World Health Organization.

WHO. (World Health Organization). (2008). Essential environmental health standards in health care. Geneva, Switzerland: World Health Organization.

Zevenhoven, R., \& Kilpinen, P. (2001). Control of Pollutants in Flue Gases and Fuel Gases. Espoo, Finland: Helsinki University of Technology. 